\title{
Thermophilic fermentations of lignocellulosic substrates and economics of biofuels: prospects in Pakistan
}

\author{
Qurat-ul-Ain Ahmad · Javed Iqbal Qazi
}

Received: 1 November 2013/Accepted: 20 March 2014/Published online: 10 April 2014

(C) The Author(s) 2014. This article is published with open access at Springerlink.com

\begin{abstract}
Climatic vicissitudes have laid further stress on already dwindling fossil fuels. In response to the emerging energy needs, biofuels can be considered as the safest and sustainable energy resources. At present, ethanol fermentations have been successful in fueling motor vehicles in some countries. However, with the existing population dynamic, obtaining ethanol from food competing resources/commodities might not be a desirable option. Therefore, non-food competing second-generation biofuels are the right choice to accommodate the increasing energy demand. Regarding the production of biohydrogen, shifting from food competing substrates to non-food competing natural resources would be geared at dawn of biohydrogen productions. In this review potential of lignocellulosic biomass, the largest renewable natural resource for biofuels' generation has been discussed in reference to economical consideration. The strategies will likely involve thermophilic microbes possessing cellulolytic as well as ethanologenic potential. The process economics might be supported to some extent by procuring byproducts of some value from the bioenergy fermentations. Nutritional evaluation of the fermentation residues for animal feed may improve the biofuel economics. The proposed strategies appear promising more specifically in reference to climatic conditions of Pakistan.
\end{abstract}

Q.-A. Ahmad ( $₫)$. J. I. Qazi

Department of Zoology, University of the Punjab,

Quaid-i-Azam Campus, Lahore 54590, Pakistan

e-mail: qurat-ul-ain.ahmad@hotmail.com

J. I. Qazi

e-mail: qazi@scientist.com
Keywords Bioethanol - Biohydrogen - Biofuel from cellulose . Thermophiles and biofuels $\cdot$ Sustainable biofuels $\cdot$ Cost-competitive biofuels

$\begin{array}{ll}\text { Abbreviations } \\ \text { LCB } & \text { Lignocellulosic biomass } \\ \mathrm{H}_{2} & \text { Hydrogen } \\ \mathrm{N}_{2} & \text { Nitrogen }\end{array}$

\section{Introduction}

The current upsurge in fossil fuels' prices, their overexploitation due to dwindling reservoirs and global awareness of environment deteriorating effects resulting from their burning have directed us to explore the substitutes [1-3]. Alarmingly high levels of carbon dioxide emission due to fossil fuels' combustion have much more worsening impact on the globe than expected ever, jumping from $355 \mathrm{ppm}$ in 1990 to $391 \mathrm{ppm}$ in 2011 [5]. Consequently, it has become mandatory to find and utilize diversified renewable and environment friendly energy sources [4]. Biofuels such as bioethanol, biodiesel and biohydrogen are considered sustainable, efficient and renewable future energy carriers with much less environmental deterioration potentials $[6,7]$.

Biofuels are basically derived from plant biomass through microbial fermentations. The established methods utilize monomeric sugars or their polysaccharide reserves which are also required for human foods. Considerable efforts are being done worldwide to develop cost-competitive processes for biofuel production [8]. For the secondgeneration biofuels, lignocellulosic materials especially 
those representing agro-industrial wastes are being advocated on one hand, while it is also claimed that compared to mesophilic conditions, thermophiles display higher potential for ethanologenic fermentation [9] and higher hydrogen production due to thermodynamic advantages with decreased processes' costs by reducing input energy [1012]. Thus thermophiles may prove cost-competitive hereafter [9]. Bioethanol has been used widely for transportation and other applications [13]. Although hydrogen is naturally unavailable as molecule, but its availability is quite practical with high energy contents $(122 \mathrm{~kJ} / \mathrm{g})$, which makes it a perfect future energy carrier. Hydrogen combustion produces only water as end product, therefore its non-polluting environmental potential is advantageous over other biofuels $[2,3]$.

Bioconversion of different organic wastes (carbon sources) to bioenergy fuels via microbial fermentations is being looked upon seriously all over the world due to its sustainable productive potential [14]. This review mainly focuses on the application of thermophilic bacteria for bioethanol and biohydrogen production processes utilizing second-generation feedstocks leading to efficient waste reduction, low $\mathrm{CO}_{2}$ emission and improved biofuel yield to achieve one of the greatest beneficial targets for the coming needs of mankind.

\section{Chemical nature of cost-competitive feedstocks for biofuel production}

Highly volatile cost of raw materials and growing criticism on use of food (starch and sugar) crops as substrates direct towards the use of lignocellulosic agri-food wastes (e.g. bagasse, wheat straw, rice straw, corn stover and municipal solid wastes) for fuel productions. The second-generation (2G) biofuels instead of using first-generation (1G) sugar streams (e.g. sugar cane, sugar palm, sugar beet, vegetables and fruits) and starch-based biomass (e.g. corn, milo, wheat, rice, potatoes, cassava, sweet potatoes and barley) $[9,15,16]$ will rely heavily upon lignocellulosic feedstocks.

Therefore, lignocellulosic biomass (LCB) is the most favorable feedstock with its rich abundance and low cost. Further its availability does not necessarily impact land use $[16,17]$. LCB makes approximately $50 \%$ of world biomass with estimated $10-50$ billion tons annual production [18]. Main components of LCB are cellulose ( $\mathrm{C}_{6}$ sugars), hemicelluloses $\left(\mathrm{C}_{5}\right.$ sugars) and lignin (polyphenols) that are tightly bound together, constituting approximately $90 \%$ of the dry matter in lignocellulosic biomass. The remaining portion of LCB comprises of extractives and ashes $[16,17]$. Actual composition of these diverse biopolymers, however, fluctuates in various plants (cellulose
36-61 \%; hemicellulose 13-39\% and lignin 6-29\%) [5, 19].

Cellulose, a syndiotactic (alternating spatial arrangement of the side chains) polymer up to several thousand glucose units of glucose molecules consists of long linear chains of $\beta(1-4)$ glycosidic linked D-glucose residues and exists as sheets of parallel chains in plant cell walls. Degradation of cellulose is a slow and costly step due to its extensive hydrogen linkages forming tightly packed crystalline matrix and cross-links to the other biopolymers i.e. hemicelluloses and lignin. Naturally, this cross-linkage of several hydroxyl groups founding the microfibrils contributes more strength to the molecule and forms a compact architecture, protecting the structure against unwanted enzymatic attack $[9,20]$.

The hemicellulose is amorphous and irregular structure comprising chiefly both linear and branched hetero-polymers of hexoses (glucose, galactose and mannose) and pentoses (xylose and arabinose). While some sugar acids (uronic acids), like glucuronic, galacturonic and methyl galacturonic acids may also be a part of the hemicellulose complex. Main chain of the molecule is basically comprised of xylan $\beta$ (1-4) linkages which in turn produce xylose (almost $90 \%$ ) and arabinose (almost $10 \%$ ) units. The hemicelluloses enriched with xyloses (in soft as well as hard woods) are usually called xylans whose composition varies in each/different feedstocks [20-22].

Lignin interferes with the hydrolysis process as it is structurally complex, hydrophobic, cross-linked aromatic biopolymer which is formed when $p$-coumaryl, coniferyl and sinapyl alcohols, the three major phenolic components undergo polymerization [23, 24].

Prior to saccharification, separation of cellulose from different polymers is necessary which can be accomplished through physical, chemical and/or biological methods. Selection of pretreatment method and downstream process depends upon the chemical nature of biomass being employed as components within the lignocellulosic materials and varies due to the origin and geographical location $[20,22]$. The extra pretreatment and hydrolysis required for conversion of complex polymers to monosaccharide sugars are the main limiting factors for biofuel production from complex LCB at industrial scale compared to $1 \mathrm{G}$ ethanol production [5].

\section{Biomass to ethanol conversion methodologies for LCB substrates}

Irrespective to the qualitative characteristics of fermentation microbes addressed above, it is considered that $2 \mathrm{G}$ feedstock-to-fuel production methodologies are undeveloped compared to $1 \mathrm{G}$ fuel production processes. Ethanol 
synthesis methodologies should be more cost-competitive with expedient techno-economic and advantageous environmental aspects. Ethanol production from LCB consists of five general steps: LCB pretreatment, LCB hydrolysis, $\mathrm{C}_{5}$ and $\mathrm{C}_{6}$ fermentations, product separation and the effluent treatment [25].

For cellulosic ethanologenesis "Separate hydrolysis and fermentation" (SHF) was known until the mid-1980s. The efforts were made for the production of cellulases, hydrolysis of cellulose and fermentation of the hydrolysates. The benefits of SHF are that each step is carried out at optimum temperature and $\mathrm{pH}$ and hemicellulose and cellulose fermentations can be performed simultaneously in single bioreactor providing the microbes being employed are capable of fermenting both hexoses and pentoses. The SHF is comparatively advantageous with mesophilic yeast/bacterial fermentations as it permits the pretreatment and hydrolysis processes freedom for temperature and $\mathrm{pH}$ etc. On the other hand glucose, the end product resulting from enzymatic hydrolysis, intensely inhibits cellulase activity, and thus represents main demerit which limits the enzymatic saccharification efficiency [9].

Simultaneous saccharification and fermentation (SSF) is a unit process that conducts enzymatic hydrolysis and ethanol fermentation together. The process' success derives from regular consumption of glucose and thus keeping its (glucose) concentration at low level keeps away the overcoming the enzyme (cellulase) inhibition phase [9, 25]. SSF is considered as an important breakthrough in the development of ethanologenesis from LCB that has been demonstrated with the Trichoderma saccharomyces ethanol production concept $[9,26]$.

Simultaneous saccharification and Co-Fermentation (SSCF) is also an analogous methodology for SSF, except it includes $\mathrm{C}_{5}$ fermentation along with $\mathrm{C}_{6}$, making ethanologenesis more cost-effective. SSF and SSCF, both are higher ethanol yielding technologies compared to SHF $[9,27,28]$. The main disadvantage of SSCF process is the inability to maintain optimum operational conditions for enzymatic hydrolysis and ethanol fermentations for mesophilic yeast and mesophilic bacteria. Conversely, with extremophilic yeasts/bacteria which are capable of producing ethanol at high temperatures $\left(50-60^{\circ} \mathrm{C}\right)$ and low $\mathrm{pH}(\mathrm{pH} 5), \mathrm{SSCF}$ is desirably carried out for different substrates $[9,29]$.

Consolidated Bioprocessing (CBP) integrates enzyme production, substrate hydrolysis, balanced consumption of available sugars (both pentoses and hexoses) and robust ethanol production in one reactor simultaneously in a single step. The process has attracted the increasing attention as a means to reduce cost and simplify the processing configuration [9, 30]. Lynd [31] proposed the concept of CBP for cellulosic ethanol production without adding external cellulases. Unfortunately, there is no such microorganism that possesses all the characteristics required to accomplish the CBP. Cellulolytic/non-cellulolytic fermentations with thermophilic co-culture anaerobes appear hopeful approaches for CBP development [9, 32]. The coculture fermentation showed speedy cellulose degradation and ethanologenesis potential in comparison with monoculture fermentation. Also improved cellulolytic degradation and ethanol yield can be obtained by genetic modification showing alternate strategy for sustainable and effective micro-organism development for CBP technology [9].

\section{Thermophilic ethanologenesis from LCB and its significance}

Originating from LCB, sugars available for ethanol fermentation can be homogenous or heterogeneous. Traditional baker's yeast, Saccharomyces cerevisae can degrade hexoses and disaccharides but unable to utilize pentoses and complex biopolymers present in LCB feedstock. That is why S. cerevisae has been immensely used for $1 \mathrm{G}$ ethanol production. This yeast has multiple significances compared to other known ethanologenic microbes which include higher ethanol yields i.e. $>1.9 \mathrm{~mol}$ of ethanol $/ \mathrm{mole}$ of hexose, higher ethanol tolerance i.e. $>12 \%$, higher robustness and higher resistance to the toxic inhibitors [5, $12,19,97]$. Another highly efficient ethanologenic microbe is Zymomonas mobilis which is a mesophilic bacterium and tolerates approximately up to $12 \%$ ethanol and has the potential of 2.5 times faster growth than yeasts [5, 33]. Thumbnail preview of lignocellulosic bioethanol production is depicted in Fig. 1. The processes of saccharification and the ability of micro-organisms to utilize both categories of monomeric sugars $\left(\mathrm{C}_{6} / \mathrm{C}_{5}\right)$ and their potential of resisting lignocellulose derived chemical inhibitors, ethanol tolerance and feedback mechanisms at various steps that potentially affect the overall ethanol yield. Thus detailed information and novel solutions of bottlenecks of the process are mandatory to develop efficient lignocellulosic bioethanol production plants.

In addition to above-mentioned attributes of ethanologenic micro-organisms, thermostability is another important characteristic influencing the fermentation efficiency positively. Thermophiles might have the same routes of oxidation and fermentation process familiar to the mesophiles. However, their thermozymes are more efficient as the biochemical reactions occur at elevated temperatures $[34,35]$.

Physical pretreatment methods employ application of heat such as steam under pressure to pave the path for 
Fig. 1 Simplified mechanism of ethanologenesis from lignocellulosic biomass. Thermophilic bacteria advantageously utilize both $\mathrm{C}_{5}$ and $\mathrm{C}_{6}$ sugars of complex biopolymers (Cellulose and Hemicellulose) for ethanologenesis and here ethanol intolerance is of lesser significance than mesophiles. Inhibitory effects on the LCB ethanologenic process are indicated as red dotted lines

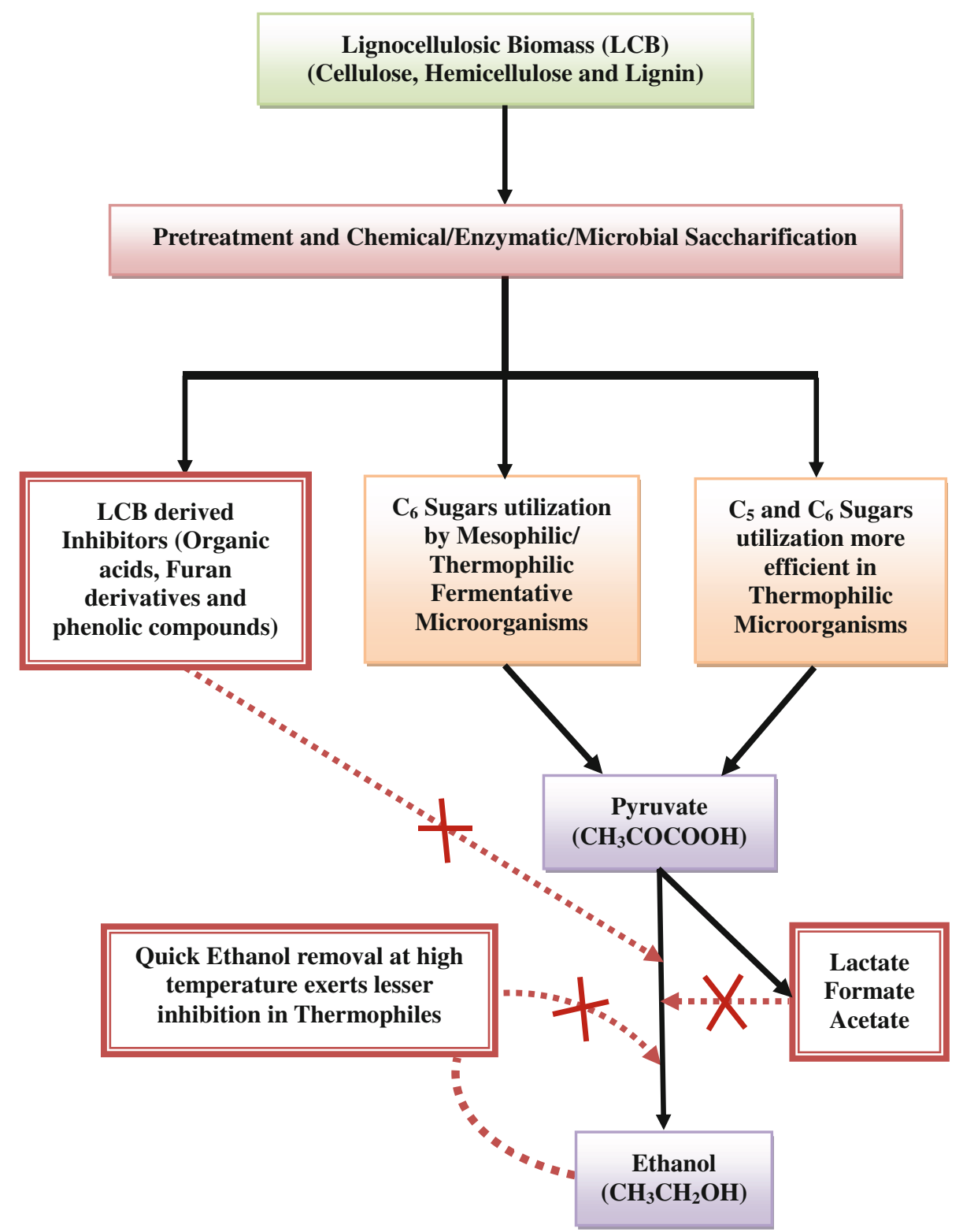

subsequent chemical hydrolysis. Chemically diluted or strong acid exposure yields streams of the monomeric sugars. Biologically/biochemically cellulases can convert, after some pretreatment of the complex LCB, the polysaccharide units into hexoses and pentoses. All the abovementioned processes provided the thermostability of the enzymes will obviously be more efficient at high temperature. But then cooling the whole system would be required. However, if the subsequent fermentation is manageable at elevated temperatures than inputs of energy can be saved [34, 36].

Ethanologenic thermophilic bacteria were first focused thoroughly in the early 1980 which kept on gaining deep attention with biotechnology advancement. The primary rationale for increased attention was oil crisis, increasing competition of crops for food and fuel and environment deteriorating impacts of fossil fuel burning [37, 38]. Figure 2 shows plausible routes for microbial pathways for ethanologenesis under thermophilic conditions utilizing LCB.

Thermophilic anaerobes grow optimally above $60{ }^{\circ} \mathrm{C}$ and have several other advantages that make them most suitable for large scale conversion of LCB to ethanol. First, they possess an efficient cellulose and hemicellulose degrading machinery along with thermostable enzymes for biomass hydrolysis and ferment broad substrate spectrum, including pentoses/hexoses to Ethanol [9, 11, 39]. Second, they possess extraordinary 
Fig. 2 Possible lignocellulosic wastes and their potential routes of bioethanol fermentations in Pakistan. The shaded boxes represent cost-competitive and ecofriendly steps for the proposed biofuels' generation processes

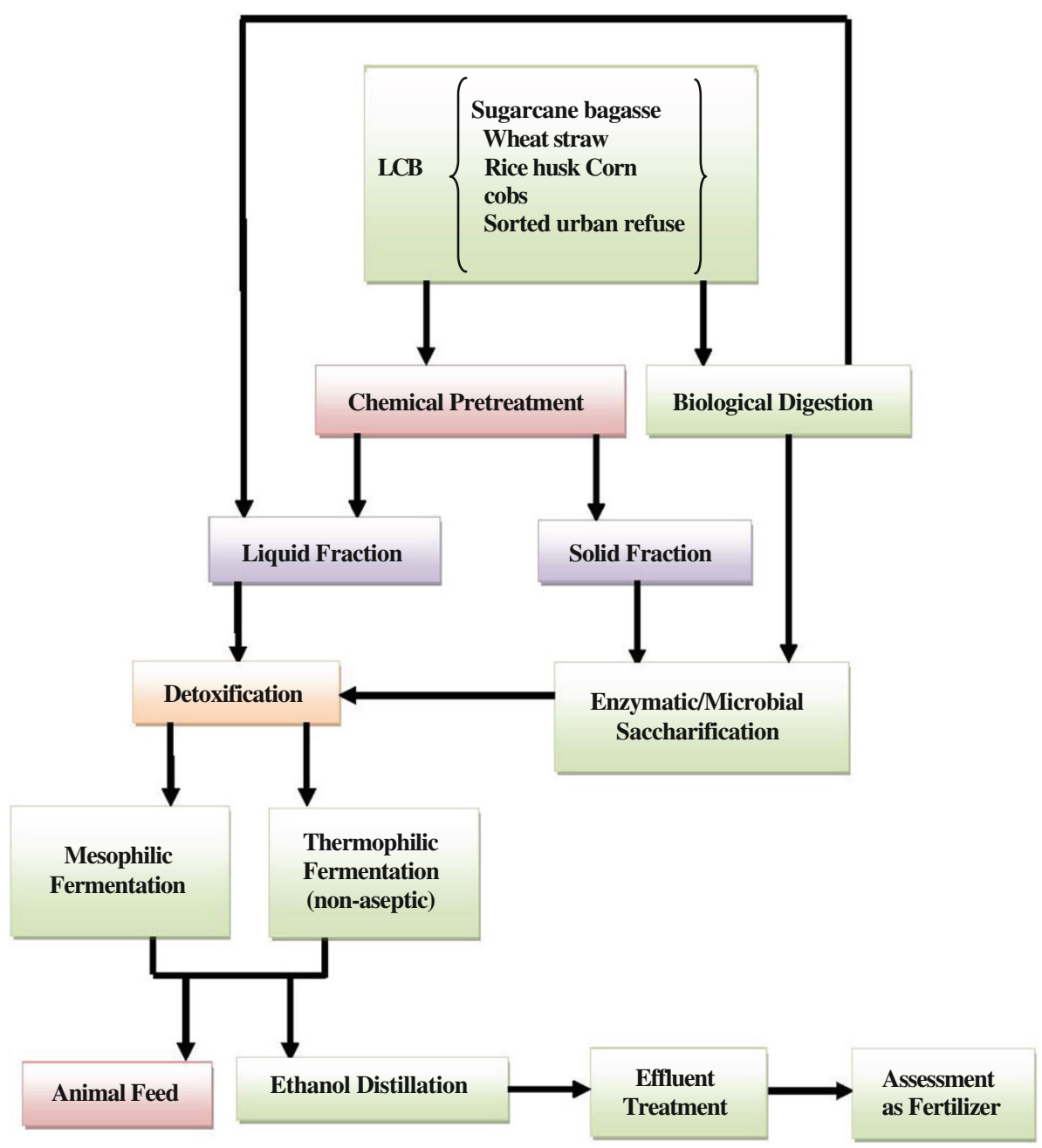

capacity to endure fluctuations in temperature, $\mathrm{pH}$ and other environmental parameters [12, 40]. Third, quick downstream product removal and recovery eliminates the problems of ethanol tolerance, substrate concentration and costly cooling systems [5, 26]. Moreover, fermentation at high temperatures reduces the risk of contamination and permits to run the process in non-aseptic condition which in turn is scalable without expensive sterilization. Significantly low gas solubility at $65{ }^{\circ} \mathrm{C}$ maintains the almost anaerobic environment, facilitating the fermentation as well as reduces the obligatory aerobic contaminants [10-12, 31]. Generally, anaerobic micro-organisms show less cell yield while converting more substrate into product i.e. high ethanol yields [26, 42]. With increased knowledge in cellulolytic and hemicellulolytic machinery of thermophiles, they have been focused for developing cost-effective ethanologenic productions utilizing LCB wastes and thus conserving the food crop supplies for humans. Also they improve process economics by reducing input energy and pretreatment requirement compared to mesophilic fermentations [9, 11].

Majority of the ethanologenic thermophiles are Grampositive and have low $\mathrm{G}+\mathrm{C}$ contents, strictly anaerobes and mostly placed in class Clostridia (phylum Firmicutes) [9, 31]. Many of them have been isolated from geothermal areas or volcanic environment such as hot springs and are also regarded promising for $2 \mathrm{G}$ processes of ethanol production [12, 39].

\section{Loopholes in the development of thermophilic ethanologenic processes}

Thermophilic ethanol producing strains are classically deficient in producing higher yields (theoretically $>90 \%$ ) as well as in tolerating high level (typically $>40 \mathrm{~g} / \mathrm{L}$ ) of ethanol and exhibit low ethanol tolerance $(<2 \%$, v/v). That is why they are not considered suitable for industrial scale ethanologenesis [9-11]. Besides above, "mixed acid 
fermentation" often contributes to low ethanol yield. Whereas the low solvent tolerance of thermophilic ethanologens to ethanol in nature can be improved through genetic engineering $[9,12,26]$. Moreover, thermophiles have low tolerance to the ${ }^{1}$ inhibitors that are produced as a result of pretreatment of LCB and often result in decreased viability as well as ethanol yields. They are more sensitive to variations in certain parameters such as biomass composition, solid content, and pretreatment dynamics (amount/type of chemicals used, temperature and $\mathrm{pH}$ etc.) than their mesophilic counterparts. It has been reported that the greatly elevated NADH/NAD ratio together with high ethanol concentration in $T$. pseudethanolicus 39E is geared back by addition of acetone (or other external electron acceptor), to maintain balanced NADH/NAD ratio. As the inside information about thermophilic Ethanol intolerance is limited, further studies are required to understand the underlying mechanisms before attempting to increase the ethanol yields from the extremophiles $[9,43]$.

\section{Biohydrogen productions}

Owing to non-polluting and high energy yielding fuel, demand for $\mathrm{H}_{2}$ is increasing remarkably, whereas its costeffective provision is lacking [45]. Fermentative $\mathrm{H}_{2}$ production exploiting mesophilic microbes has been recognized since 1920s [5, 45].

Broadly, hydrogen production processes via biological means can be categorized into three types: biophotolysis of water using algae and cyanobacteria which is sub-divided into direct and indirect biophotolysis; photofermentation which is actually the photodecomposition of biological compounds utilizing phototrophic bacteria; and fermentation of organic compounds i.e. dark fermentation (utilizing wastes or food crops) [2, 46-48].

All types of biological hydrogen production processes involve two groups of enzymes, either hydrogenases or nitrogenases, deriving photo-energy directly or indirectly by utilizing photosynthetically produced carbon compounds. Nitrogenase is a metalloprotein complex which when performs $\mathrm{N}_{2}$ fixation in excess, forms $\mathrm{H}_{2}$ as a byproduct as shown in the following equation [48-50]:

Nitrogenase reaction:

$$
\begin{aligned}
& \mathrm{N}_{2}+8 \mathrm{H}^{+}+8 \mathrm{e}^{-}+16 \mathrm{ATP} \\
& \quad \rightarrow 2 \mathrm{NH}_{3}+\mathrm{H}_{2}+16 \mathrm{ADP}+16 \mathrm{P}_{\mathrm{i}}
\end{aligned}
$$

\footnotetext{
${ }_{1}^{1}$ Inhibitors are the compounds produced during LCB pretreatment which influence the microbial fermentation negatively. For detailed information, see [97].
}

Hydrogenases are the key enzymes of biological $\mathrm{H}_{2}$ metabolism catalyzing either $\mathrm{H}_{2}$ oxidation for forming reducing equivalents and protons or reducing protons for producing molecular hydrogen $[46,51]$ :

Hydrogenase reaction: $2 \mathrm{H}^{+}+2 \mathrm{e}^{-} \rightarrow \mathrm{H}_{2}$

On the basis of harboring metal atoms, settled exclusively in their dinuclear active centers, hydrogenases are grouped into three categories: $\mathrm{FeFe}$ hydrogenases, $\mathrm{NiFe}$ hydrogenases and at last the metal-free hydrogenases [49, $50,52]$.

Direct biophotolysis is a biological process that uses the plant-type photosynthetic potential of green algae and blue green algae (cyanobacteria) of splitting water utilizing the captured light energy and reducing ferredoxin. This final electron acceptor further reduces the oxygen sensitive key enzymes, hydrogenase or nitrogenase involved in $\mathrm{H}_{2}$ and $\mathrm{O}_{2}$ productions by concomitant transfer of electrons [4648, 50]:

$$
2 \mathrm{H}_{2} \mathrm{O}+\text { Light energy } \rightarrow 2 \mathrm{H}_{2}+\mathrm{O}_{2}
$$

For capturing enough solar energy, expensive hydrogen impermeable photobioreactors are required which increase the cost for $\mathrm{H}_{2}$ production [46]. Efficiencies close to $10 \%$ (maximum reported efficiency) have been demonstrated under optimized conditions of light and oxygen but unluckily, these parameters are too costly to sustain at large scale.

Indirect biophotolysis is more advantageous as $\mathrm{O}_{2}$ and $\mathrm{H}_{2}$ evolution steps proceed separately (utilizing vegetative and heterocyst cells) that is why it is named as indirect biophotolysis. It comprises of two steps: first, photosynthetic biomass is produced and second anaerobic dark fermentation of the photosynthesized biomass is done for the production of $\mathrm{H}_{2}$ [53]:

In vegetative cyanobacterial cells:

$$
6 \mathrm{CO}_{2}+6 \mathrm{H}_{2} \mathrm{O}+\text { Light } \rightarrow \mathrm{C}_{6} \mathrm{H}_{12} \mathrm{O}_{6}+\mathrm{O}_{2}
$$

In cyanobacterial heterocyst:

$$
\mathrm{C}_{6} \mathrm{H}_{12} \mathrm{O}_{6}+6 \mathrm{H}_{2} \mathrm{O}+\text { Light } \rightarrow 6 \mathrm{CO}_{2}+12 \mathrm{H}_{2}
$$

Photofermentative hydrogen production is one of the central sunlight-dependent biohydrogen production processes utilizing light as energy source (Fig. 3). As can be seen from this figure, the usual route of solar energy conversion can be rendered highly efficient through interventions of photo-biohydrogen fermentation. In this process electrons and protons produced through oxidation of organic compounds are used to form molecular hydrogen under anaerobic and nitrogen-limited conditions. Photoheterotrophic bacteria have the potential of producing not only substantial amounts of hydrogen [50,54] but 
Fig. 3 Photo-fermentative hydrogen production photosynthesis for fixing the solar energy. The direct route of plant biomass for animal feeding appears less efficient in terms of solar energy conversion efficiencies as the proposed way opens two more avenues of bio $\mathrm{H}_{2}$ and single cell proteins in addition to herbivorous energy conversion route supplements the plant

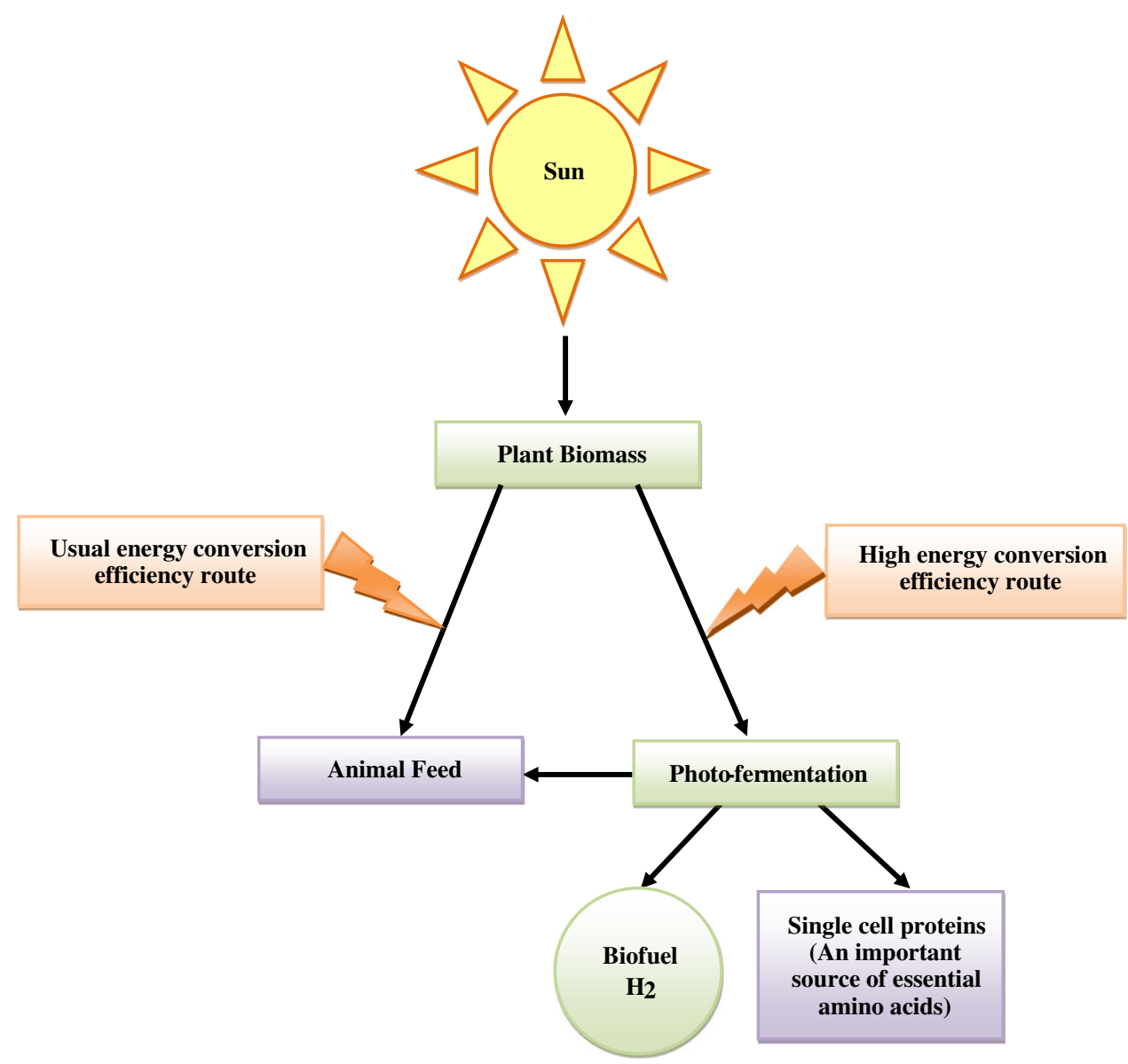

are also beneficial as they solve organic waste disposal problems along with the production of the clean bioenergy fuel $\mathrm{H}_{2}$.

A variety of photosynthetic bacteria are reported to produce $\mathrm{H}_{2}$ in nature, the most famous out of them are purple non-sulfur bacteria (PNSB). Biological nitrogen fixation, catalyzed by nitrogenase, is the major route for $\mathrm{H}_{2}$ production by PNSB forming $1 \mathrm{~mol} \mathrm{H}_{2} / \mathrm{mol} \mathrm{N} \mathrm{N}_{2}$ fixed utilizing $16 \mathrm{~mol}$ of ATP. This is, but in the presence of nitrogen sources, however, an inefficient $\mathrm{H}_{2}$ production process as about $75 \%$ of the reductant consumed by the nitrogenase is used to generate ammonia [50, 55]:

$\mathrm{NH}_{3}+8 \mathrm{H}^{+}+8 \mathrm{e}^{-}+16 \mathrm{ATP}$
$\quad \rightarrow \mathrm{NH}_{3}+\mathrm{H}_{2}+16 \mathrm{ADP}+16 \mathrm{P}_{\mathrm{i}}$

But under nitrogen deficient conditions, nitrogenase produces $\mathrm{H}_{2}$ using $4 \mathrm{~mol}$ of $\mathrm{ATP}$, so the $\mathrm{H}_{2}$ production efficacy increases by four times with the same energy input:

$2 \mathrm{H}^{+}+2 \mathrm{e}^{-}+4 \mathrm{ATP} \rightarrow \mathrm{H}_{2}+4 \mathrm{ADP}+4 \mathrm{P}_{\mathrm{i}}$

Bidirectional NiFe hydrogenases of PNSB may also create an improved concern for $\mathrm{H}_{2}$ production exploiting photosynthetic bacteria $[50,56]$.
Forming $\mathrm{H}_{2}$ through photosynthesis is one of the features of cyanobacteria. The cyanobacterium Anabaena variabilis has been reported to have the highest yields of $0.355 \mathrm{mmol} \mathrm{H}_{2} /$ liter $[47,57]$. Still this process is estimated to be economically not well-balanced, mostly due to the high production cost of the photobioreactors [58]. The above-mentioned constrains have guided the scientists to look towards the dark hydrogen fermentation.

Dark hydrogen fermentation is considered the most developed technology for biohydrogen production owing to its higher production efficiency, simple control requirements, lower operating costs and long production without light compared to phototrophic hydrogen production [2, 46, 47]. A wide range of heterotrophic bacteria have the capability of carrying out anaerobic fermentation to produce $\mathrm{H}_{2}$ and $\mathrm{CO}_{2}$, volatile fatty acids (VFAs) and solvents $[6,59]$. Dark microbial $\mathrm{H}_{2}$ production is carried out by the anabolic metabolism of the key intermediate, pyruvate, generated by glycolysis which is oxidized to acetyl CoA. Upon complete oxidation of glucose, a stoichiometric yield of $12 \mathrm{H}_{2} \mathrm{~mol} / \mathrm{glucose} \mathrm{mol}$ is obtained without any energy flow to support growth and metabolism of the producing organisms [46, 60]. However, in all the microbial 
fermentation processes, hydrogen is produced along with volatile fatty acids/alcohols and its stechiometric yield of $12 \mathrm{~mol} \mathrm{H}_{2} / \mathrm{mol}$ glucose is never attained in any known biological in vivo system as some glucose is always consumed for the growth and maintenance of the microbes [61, 62].

In microbial fermentations, $\mathrm{H}_{2}$ yields depend on the fermentation pathways used and the end products formed. The maximum theoretical yield of $\mathrm{H}_{2}$ is 4 mol per mol of glucose both from hexoses and pentoses and is obtainable with acetate as the fermentation product (Eqs. 8 and 9) $[63,64]$ :

$$
\mathrm{C}_{6} \mathrm{H}_{12} \mathrm{O}_{6}+2 \mathrm{H}_{2} \mathrm{O} \rightarrow 2 \mathrm{CH}_{3} \mathrm{COO}^{-}+2 \mathrm{CO}_{2}+2 \mathrm{H}^{+}+4 \mathrm{H}_{2}
$$

$$
\begin{aligned}
\mathrm{C}_{5} \mathrm{H}_{10} \mathrm{O}_{5}+1.67 \mathrm{H}_{2} \mathrm{O} \rightarrow & 1.67 \mathrm{CH}_{3} \mathrm{COO}^{-}+1.67 \mathrm{CO}_{2} \\
& +1.67 \mathrm{H}^{+}+3.33 \mathrm{H}_{2}
\end{aligned}
$$

If butyric acid or more reduced end products compared to acetate, such as butyrate, propionate and alcohols (ethanol, butanol) are the final end products, the theoretical value decreases to $2 \mathrm{~mol}$ of $\mathrm{H}_{2}$ per mol or more of glucose utilized $[5,64,65]$ :

$$
\begin{aligned}
\mathrm{C}_{6} \mathrm{H}_{12} \mathrm{O}_{6}+2 \mathrm{H}_{2} \mathrm{O} \rightarrow & \mathrm{CH}_{3} \mathrm{CH}_{2} \mathrm{CH}_{2} \mathrm{COO}^{-}+2 \mathrm{H}_{2} \\
& +2 \mathrm{HCO}_{3}^{-}+3 \mathrm{H}^{+}
\end{aligned}
$$

\section{Significance of thermophilic biohydrogen fermentation}

Fermentations can be performed under mesophilic $\left(25-40{ }^{\circ} \mathrm{C}\right)$, thermophilic $\left(40-65{ }^{\circ} \mathrm{C}\right)$, extreme-thermophilic $\left(65-80{ }^{\circ} \mathrm{C}\right)$, and hyper-thermophilic $\left(>80^{\circ} \mathrm{C}\right)$ conditions [47, 66, 67]. Karadag [41] described that thermophiles have the potential to produce up to $60-80 \%$ of the theoretical maximum production of $4 \mathrm{~mol}$ of $\mathrm{H}_{2} /$ mole glucose. It has been reported that at thermophilic conditions, $\mathrm{H}_{2}$ yield was higher due to limited growth of $\mathrm{H}_{2}$ consumers and faster metabolic activity of bacteria. Thermophilic yield of $3.8 \pm 0.2 \mathrm{~mol} \mathrm{H}_{2} \mathrm{~mol}^{-1}$ glucose using co-culture of extremophiles; Caldicellulosiruptor kristjanssonii and Caldicellulosiruptor saccharolyticus has been reported. Similarly, for the bacterium with Caldicellulosiruptor owensensis while employing glucose as carbon source supplemented with a rich vitamin solution has been reported a yield of $3.8 \pm 0.1 \mathrm{~mol} \mathrm{H}_{2} \mathrm{~mol}^{-1}$ glucose with a formation rate of $15 \mathrm{mmol} \mathrm{H}_{2} \mathrm{~L}^{-1} \mathrm{~h}^{-1}[50,51,68]$.

Application of thermophilic microbes for biological $\mathrm{H}_{2}$ production seems to be more favorable substitute to the existing $\mathrm{H}_{2}$ production technologies. For this purpose, there is an ultimate need of understanding carbon and $\mathrm{H}_{2}$ metabolic pathways in thermophilic bacteria which are still not absolutely understood. Appropriate hydrolysis of $\mathrm{C}_{5}$ and $\mathrm{C}_{6}$ sugars from lignocellulosic biomass depends upon the metabolic routes utilized and is crucial for maximum yield of fermentative $\mathrm{H}_{2}$ production. As a whole, thermophilic bacteria exploit as a minimum three metabolic routes for hydrogen production [44].

Most of the extreme-thermophilic members of Phylum Clostridia utilize the "Embden-Meyerhof pathway" for $\mathrm{H}_{2}$ fermentation. In the first route, NADH, formed in the Embden-Meyerhof pathway, is utilized by NADH-dependent Fe-only $\mathrm{H}_{2}$ ase to evolve $\mathrm{H}_{2}$ according to the following equation $[44,69]$ :

$\mathrm{NADH}+\mathrm{H}^{+} \rightarrow \mathrm{NAD}^{+}+\mathrm{H}_{2}$

The second route consumes reduced ferredoxin (Fdred) by an $\mathrm{Fd}$-dependent $\mathrm{Ni}-\mathrm{Fe}-\mathrm{H}_{2}$ ase which transfers electrons from Fdred to protons for making $\mathrm{H}_{2}$ according to the equation given below [44, 70]:

2 Fdred $+2 \mathrm{H}^{+} \rightarrow 2$ Fdox $+\mathrm{H}_{2}$

Alternately a FeFe bifurcating heterotrimeric hydrogenase uses both Fdred and NADH at the same time to produce $\mathrm{H}_{2}$ by the following reaction [44, 71]:

$2 \mathrm{NADH}+4$ Fdred $+6 \mathrm{H}^{+} \rightarrow 4 \mathrm{H}_{2}+2 \mathrm{NAD}^{+}+4 \mathrm{Fdox}$

Reduction potential $\left(\mathrm{EO}^{\prime}\right)$ for the $\mathrm{NADH} / \mathrm{NAD}^{+}$pair is found to be $-320 \mathrm{mV}$, for the Fdred/Fdox pair it equals $-400 \mathrm{mV}$ and midpoint potential for the exergonic oxidation of $\mathrm{Fd}$ is suggested as $E_{\mathrm{m}}=-453 \mathrm{mV}$, and $\mathrm{E}^{\prime}=$ $-420 \mathrm{mV}$ for driving the NADH endergonic oxidation for the production of $\mathrm{H}_{2}$ by the trimeric [FeFe] bifurcating hydrogenase [44, 71, 72].

Thermophiles have high growth rates and they have the ability to ferment a broad range of substrates [9]. These bacteria can efficiently utilize cellulose, thus they are extremely capable of producing $\mathrm{H}_{2}$ from the complex polymer without the need of adding external cellulase. Extreme-thermophilic condition offers more effective pathogenic destruction [73] and reduces the risk of growing unwanted bacterial contaminants such as methanogens and solvent-producing bacteria [74], while on the other hand hydrogen utilization process is negatively affected at elevating temperature [75]. Also, thermophilic fermentation compared with mesophiles produces less variety of end products [67] and higher hydrogen yields [28, 49]. Hydrolysis of complex biopolymers including household solid waste (HSW) and manure could be noticeably improved by switching the fermentation temperature from mesophilic or thermophilic to extreme-thermophilic condition [76, 77]. Although working at extreme-thermophilic temperatures may cause higher cost for heating, but in selected situation this could be compensated from energy saving which are otherwise required in case of mesophilic fermentations. Mixed culture fermentation for hydrogen production is more suitable for industrial application [78] 
than pure culture fermentation, because it does not need sterilization of media, has increased adaptation capacity offered by its high microbial diversity and possibility of mixed substrates co-fermentation [79].

Furthermore at increasing temperatures, hydrogen-producing metabolism becomes less influenced negatively by the $\mathrm{H}_{2}$ partial pressure in liquid phase [74]. In addition, gas solubility is remarkably lower at $65^{\circ} \mathrm{C}$ compared to $37{ }^{\circ} \mathrm{C}$. Thermophilic fermentations reduce input energy needed to cool mesophilic fermentations after feedstock pretreatment and distillation process after fermentation [10, 11], thus they may prove to be cost-competitive [9].

\section{Critical parameters for thermophilic biohydrogen production}

Efficiency of dark fermentative $\mathrm{H}_{2}$ production processes can be influenced by various parameters such as $\mathrm{pH}$, nutritional requirements, temperature and partial pressure of $\mathrm{H}_{2}[6,51,62,80]$. Ideal $\mathrm{pH}$ and temperature ranges are from 6.8 to 7.5 and 31 to $36{ }^{\circ} \mathrm{C}$ [81], respectively, while for the photofermentation optimal wavelengths fell between 400 and $1,000 \mathrm{~nm}[51,82,83]$ and light intensities are detected between 6 and 10 klux $[48,78]$. As $\mathrm{H}_{2}$ production occurs at acidogenic stage, many researchers found 5.5-6.5 pH optimal [2, 51, 62]. However, recently dark $\mathrm{H}_{2}$ fermentation at alkaline conditions $(\mathrm{pH} \mathrm{10)}$ is proposed to limit byproduct formation and inhibit $\mathrm{H}_{2}$ consuming acetogenic bacteria while using waste activated sludge as substrate [51]. Additional benefits of high $\mathrm{pH}$ processes include pretreatment of biopolymeric substrates and reduced risk of neutrophilic contaminations. However, this also necessitates the search of alkaliphilic photofermentative microbes.

Nitrogen, phosphorous, iron and sulfur are central nutrient elements in dark fermentative $\mathrm{H}_{2}$ production [6]. $\mathrm{Fe}$ and Mo are the most important cofactors reported for nitrogenase enzyme activity for $\mathrm{H}_{2}$ production [51]. Whereas overuse of nitrogen has negative effects on $\mathrm{H}_{2}$ production since even $20 \mu \mathrm{M}$ of ammonia has been reported to cause inhibition on the nitrogenase enzyme responsible for $\mathrm{H}_{2}$ formation. Malate/glutamate ratio larger than 1 is considered most suitable for effective photofermentative $\mathrm{H}_{2}$ production [83] and optimum VFA concentrations range from 1,800 to $2,500 \mathrm{mg} \mathrm{L}^{-1}$ [51, 84]. Optimum ratios for $\mathrm{COD} / \mathrm{N}$ range between $11.4 / 1$ and 200/1 and for COD/P between 73/1 and 970/1 [50, 80, 85].

$\mathrm{H}_{2}$ gas formation rate (HPR) and $\mathrm{H}_{2}$ yield are the two utmost critical parameters for selection of most fermentative $\mathrm{H}_{2}$ producing bacteria. By definition yield is the amount of $\mathrm{H}_{2}$ produced per amount of substrate consumed (mole of $\mathrm{H}_{2} /$ mole of glucose) and HPR is the amount of $\mathrm{H}_{2}$ $(\mathrm{ml})$ produced per unit time and per unit reactor volume (volumetric rate) or per unit biomass (specific rate) [50, 86].

\section{Future directions for biofuel development in Pakistan}

Pakistan is suffering from stark economic crisis because of its remarkably increasing gap between energy requirements and current provision. By 2011-2012, immense energy outage is considered to be the primary cause of constrained development in a number of industrial sectors. The government of Pakistan has expended US $\$ 9$ billion for importing energy fuels in 2008-2009 to satisfy present energy demands. Locally available energy resources (primarily the fossil fuels) are now depleting due to overexploitation not only in Pakistan but also worldwide. Therefore, new workable energy resources exploiting the renewable biomass are needed to be explored so that the constrain on country's economy could be reduced to some extent [7, 87].

Solar energy in Pakistan is one of the most abundantly available renewable energy source that if exploited properly carries the potential of fulfilling the increasing energy needs and reducing import bills and atmospheric emissions of the country. Ideally out of 365 days in a year, more than "300 days" are sunny within Pakistan [88, 89]. Moreover, Pakistan has remarkably favorable geographical locations and climatic conditions for bioenergy production if its vast wastelands, agricultural and lignocellulosic-rich biomass wastes are utilized properly. The "Alternative Energy Development Board" (AEDB) in Pakistan is encouraging the private investors of the country to take an active part in the production of biofuels for increasing their profitability [90, 91].

Qazi [35] articulated the non-pathogenic behavior of thermophiles along with their highly thermostable enzymes, making them exceptionally eligible for scheming microbial bioprocesses for productions of energy fuels in non-aseptic and thus less energy intensive ways. Especially in resource-deprived countries like Pakistan, it is advisable to facilitate the provision of thermo-biofuel refineries in climatically suitable warm areas for developing sustainable and cost-competitive energy production systems with minimum input values. Some of such locations are mentioned in Table 1.

It is interesting to note that ethanologenic thermophiles' temperature optima are very near to the ambient temperature ranges of the areas mentioned in the table. For example, Clostrdium thermocellum has been reported for its temperature optima of $55-60{ }^{\circ} \mathrm{C}$ with an ethanol yield of 4.6-5.1 g/l using cellulose as substrate [98]. 
Table 1 Some locations of Pakistan with recorded temperature above $50{ }^{\circ} \mathrm{C}$ indicating the extremely warm summer

\begin{tabular}{llll}
\hline Dates & Temperature $\left({ }^{\circ} \mathrm{C}\right)$ & City/province of Pakistan & Reference \\
\hline May 22 to May 26, 2010 & 53 & Sibi/Balouchistan & Information \\
May 24 to May 27, 2010 & 53 & Jacobabad/Sindh & \\
May 27, 2010 & 50 & Multan/Punjab & \\
May 26 to May 29, 2009 & 52 & Turbat/Balouchistan & \\
June 10, 2007 & 50 & Bannu/Khyber Pakhtunkhwa & \\
June 9 to June 10, 2007 & 51 & Sargodha/Punjab & \\
\hline
\end{tabular}

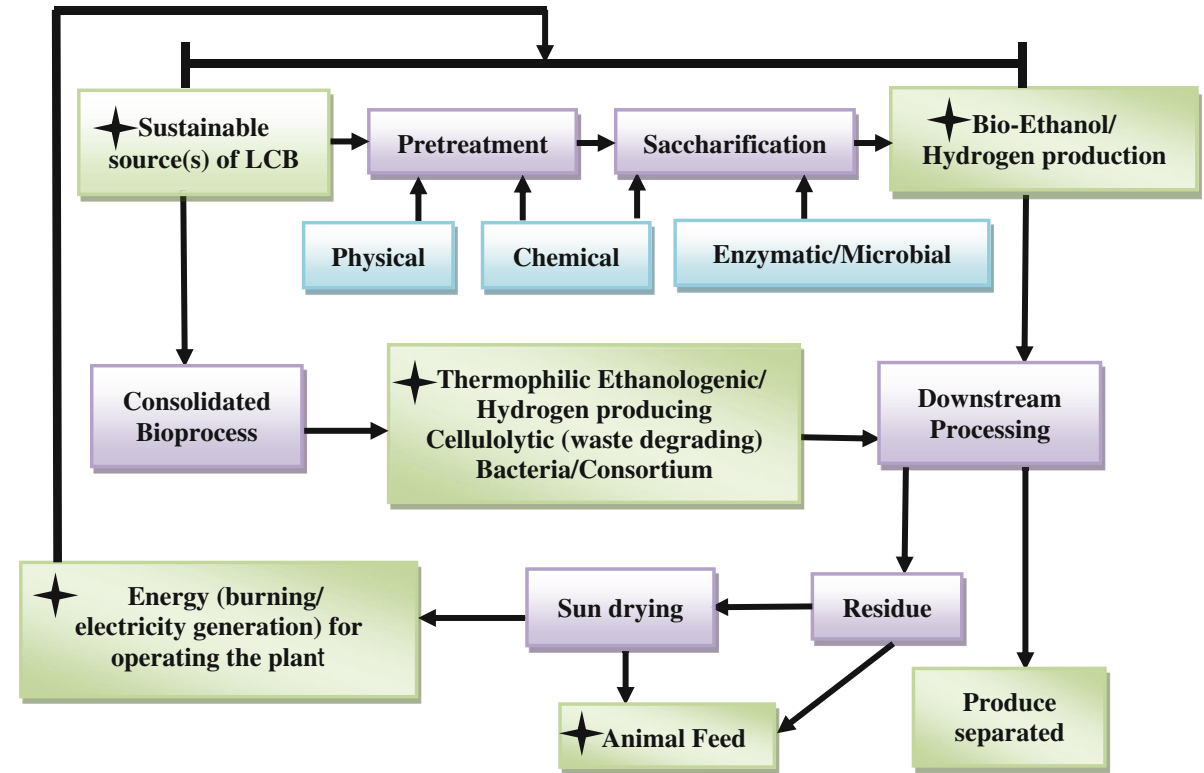

Fig. 4 A general layout for cost-effective biofuel productions by employing thermophilic bacteria. For the fuel production plants localized in climatically cold areas, heat has to be supplied but saving might be procured from less/no cooling requirements for the formation as well as the condensation process needed to separate the produce. For the fuel production plants localized in climatically warm areas like Pakistan, less intensive efforts are required for

Pakistan is the world's fifth largest producer of sugarcane in terms of acreage, and the 15th largest producer of sugar. Sugarcane bagasse is a fibrous waste product of the sugar refining industry, comprised of LCB. Pakistan produces more than 12 million tons of the bagasse, which being LCB contains significant amounts of nutrients [92]. Currently, the LCB wastes are either used as fuel for electricity generation or contribute in environmental pollution. Right now, on large scale, sugarcane-based ethanol is produced in Pakistan from molasses only. It is estimated that 240-270 1 ethanol/ton of molasses is produced in Pakistani distillery units usually connected to sugar mills [91, 93, 94].

Some workers from Pakistan have reported potentials of locally isolated bacteria and yeast capable of ethanol fermentation from sugarcane bagasse and wastes fruits. For supplying heat to the plant thus saving energy while cooling for condensation will be required somehow. In addition, burning/ electricity generations as well as animal feed production from fermentation residues may further economize the bioenergy production processes. $(\uparrow$ Cost-effective step for bioethanol/hydrogen production)

example, it is reported that the ethanologenesis from aqueous extract and acid hydrolyzates of sugarcane bagasse [95]. Further, the comparative significance of thermophilic ethanologenic micro-organisms from decayed fruits and vegetables in a series of experiments with respect to mesophilic ethanologenic micro-organisms is well established [96]. The above-mentioned studies permit to propose sugarcane bagasse and other locally available LCBs as workable substrates for biofuel production processes. The proposal would be extremely cost-competitive as on one hand biofuels will be generated out of wastes while on the other hand the residues/left overs would again be available as animal feed supplement and/or for electricity generation. Flow diagram (Fig. 4) shows the general layout of the proposed cost-competitive, ecofriendly fuel production process. 


\section{Conclusion}

Appropriate extraction of energy by utilizing lignocellulosic agro-industrial wastes as substrates for large scale production of ethanol and hydrogen biofuels can be highly beneficial for coming out of the current energy depletion and its associated environmental and political crisis. For this purpose it is extremely important to understand the microbial metabolic pathways involved in biofuel generation utilizing the lignocellulosic biomass. Biofuel production in thermophilic conditions is also considered more sustainable and the extreme condition provides high selection pressure maintaining the process continuity in an essentially non-aseptic environment saving cost of sterilization. This review highlights the potential of LCB in terms of its constituents which can be mobilized for ethanol and hydrogen fermentations with special note on the development of non-aseptic processes. These processes have been introduced in scenario of saving of energy inputs incurred on sterilization. While elevated fermentation temperature has an advantage of ethanol recovery simultaneously solving the problem of ethanol tolerance of microbes involved. Likewise at thermophilic condition higher $\mathrm{H}_{2}$ yield has been documented due to limited growth of hydrogen consuming contaminants and faster metabolic activities of the producers. Pakistan has prolonged warm summer season and thus microbes thriving in extreme conditions of temperature are available naturally. The exploitation of locally available high temperature and solar energy for lignocellulosic biofuel production should be the focus of our future research work for development of cost-competitive and ecofriendly biofuels' generation processes. These renewable bioenergy fuels would not only be a constant sustainable resource but will also pose less environmental risks compared to the conventional non-renewable fossil fuels' usage.

Acknowledgments We wish to express our deepest appreciation and gratitude to our families and friends and everyone who helped and guided us in writing this review article.

Conflict of interest In connection to the submitting of review article, "Thermophilic Fermentations of Lignocellulosic Substrates and Economics of Biofuels: Prospects in Pakistan" to the "International Journal of Energy and Environmental Engineering", the authors declare no competing interest for this article.

Authors' contributions QA searched all the relevant literature according to the design of study. She prepared the draft of the manuscript after acquisition of proper interpretation. QA also developed the figures of the manuscript. JIQ conceived the design of study and revised critically the manuscript draft. In addition, JIQ gave inputs in the intellectual content of developed figures.
Open Access This article is distributed under the terms of the Creative Commons Attribution License which permits any use, distribution, and reproduction in any medium, provided the original author(s) and the source are credited.

\section{Referencess}

1. Ammo, O.M., Fagbenle, R.L.: Renewable municipal solid waste pathways for energy generation and sustainable development in the Nigerian context. Int. J. Energy Environ. Eng. 4, 42 (2013)

2. Kapdan, I.K., Kargi, F.: Bio-hydrogen production from waste materials. Enzyme Microb. Technol. 38(5), 569-582 (2006)

3. Ciranna, A., Santala, V., Karp, M.: Enhancing biohydrogen production of the alkalithermophile Thermobrachiumcelere. Int. J. Hydrog. Energy 37(7), 5550-5558 (2012)

4. Pandyaswargo, A.H., Onoda, H., Nagata, K.: Energy recovery potential and life cycle impact assessment of municipal solid waste management technologies in Asian countries using ELP model. Int. J. Energy Environ. Eng. 3, 28 (2012)

5. Sveinsdottir M, Sigurbjornsdottir MA, Orlygsson J: From ethanol and hydrogen production with thermophilic bactera from sugars and complex biomass. In: Shaukat, S.S. (ed.) Progress in Biomass and Bioenergy production, pp. 359-394 (2011). doi:10.5772/ 17404

6. Hawkes, F., Hussy, I., Kyazze, G., Dinsdale, R., Hawkes, D.: Continuous dark fermentative hydrogen production by mesophilic microflora: principles and progress. Int. J. Hydrog. Energy 32(2), 172-184 (2007)

7. Saif, U., Rehman, M., Rashid, N., Saif, A., Mahmood, T., Han, J.I.: Potential of bioenergy production from industrial hemp (Cannabis sativa): Pakistan perspective. Renew. Sust. Energy Rev. 18, 154-164 (2013)

8. Barnard, D., Casanueva, A., Tuffin, M., Cowan, D.: Extremophiles in biofuel synthesis. Environ. Technol. 31(8-9), 871-888 (2010)

9. Chang, T., Yao, S.: Thermophilic, lignocellulolytic bacteria for ethanol production: current state and perspectives. Appl. Microbiol. Biotechnol. 92(1), 13-27 (2011)

10. Zaldivar, J., Nielsen, J., Olsson, L.: Fuel ethanol production from lignocellulose: a challenge for metabolic engineering and process integration. Appl. Microbiol. Biotechnol. 56(1-2), 17-34 (2001)

11. Dien, B.S., Cotta, M.A.: Jeffries TW: bacteria engineered for fuel ethanol production: current status. Appl. Microbiol. Biotechnol. 63, 258-266 (2003)

12. Taylor, M.P., Eley, K.L., Martin, S., Tuffin, M.I., Burton, S.G., Cowan, D.A.: Thermophilic ethanologenesis: future prospects for second-generation bioethanol production. Trends Biotechnol. 27(7), 398-405 (2009)

13. Balat, M., Balat, H., Oz, C.: Progress in bioethanol processing. Prog. Energy Combust. Sci. 34, 551-573 (2008)

14. Wongthanate, J., Chinnacotpong, K., Khumpong, M.: Impacts of $\mathrm{pH}$, temperature, and pretreatment method on biohydrogen production from organic wastes by sewage microflora. Int. J. Energ. Environ. Eng. 5, 6 (2014)

15. Hahn-Hagerdal, B., Galbe, M., Gorwa-Grauslund, M.F., Liden, G., Zacchi, G.: Bio-ethanol-the fuel of tomorrow from the residues of today. Trends Biotechnol. 24, 549-556 (2006)

16. Balat, M.: Production of bioethanol from lignocellulosic materials via the biochemical pathway: a review. Energy Convers. Manage. 52, 858-875 (2011)

17. Menon, V., Rao, M.: From recent trends in valorization of lignocellulose to biofuel. In: Satyanarayana, T., Prakash, A., Johri (eds.) Microorganisms in Sustainable Agriculture and Biotechnology, pp. 381-409 (2012) 
18. Sanchez, O., Cardona, C.: Trends in biotechnological production of fuel ethanol from different feedstocks. Bioresour. Technol. 99, 5270-5295 (2008)

19. van Maris, A.J.A., Abbott, D.A., Bellissimi, E., van den Brink, J., Kuyper, M., Luttik, M.A.H., Wisselink, H.W., Scheffers, W.A., van Dijken, J.P., Pronk, J.T.: Alcoholic fermentation of carbon sources in biomass hydrolysates by Saccharomyces cerevisiae: current status. Antonie Van Leeuwenhoek 90, 391-418 (2006)

20. Limayem, A., Ricke, S.C.: Lignocellulosic biomass for bioethanol production: current perspectives, potential issues and future prospects. Prog. Energy Combust. Sci. 38(4), 449-467 (2012)

21. Kapoor, M., Kapoor, R.K., Kuhad, R.C.: Differential and synergistic effects of xylanase and laccase mediator system (LMS) in bleaching of soda and waste pulps. J. Appl. Microbiol. 103, 305-317 (2007)

22. Olofsson, K., Bertilsson, M., Liden, G.: A short review on SSF an interesting process option for ethanol production from lignocellulosic feedstocks. Biotechnol. Biofuels (2008). doi:10.1186/ 1754-6834-1-7

23. Menon, V., Rao, M.: Trends in bioconversion of lignocellulose: biofuels, platform chemicals \& biorefinery concept. Prog. Energy Combust. Sci. 38, 522-550 (2012)

24. Canilha, L., Chandel, A.K., Milessi, T.S.D.-S., Antunes, F.A.F., Freitas, W.L.D.-C., Felipe, M.D.-G.A., da Silva, S.S.: Bioconversion of sugarcane biomass into ethanol: an overview about composition, pretreatment methods, detoxification of hydrolysates, enzymatic saccharification, and ethanol fermentation. J. Biomed. Biotechnol. 2012, 1-15 (2012). doi:10.1155/2012/ 989572

25. Cardona, C.A., Sanchez, O.J.: Fuel ethanol production: process design trends and integration opportunities. Bioresour. Technol. 98(12), 2415-2457 (2007)

26. Demain, A.L., Newcomb, M., Wu, J.H.D.: Cellulase, clostridia, and ethanol. Microbiol. Mol. Biol. R. 69, 124-154 (2005)

27. Ballesteros, M., Oliva, J.M., Negro, M.J., Manzanares, P., Ballesteros, I.: Ethanol from lignocellulosic materials by a simultaneous saccharification and fermentation process (SFS) with Kluyveromycesmarxianus CECT 10875. Process Biochem. 39(12), 1843-1848 (2004)

28. Kadar, Z., Szengyel, Z., Reczey, K.: Simultaneous saccharification and fermentation (SSF) of industrial wastes for the production of ethanol. Ind. Crop Prod. 20, 103-110 (2004)

29. Abdel-Banat, B.M.A., Hoshida, H., Ano, A., Nonklang, S., Akada, R.: High-temperature fermentation: how can processes for ethanol production at high temperatures become superior to the traditional process using mesophilic yeast? Appl. Microbiol. Biotechnol. 85, 861-867 (2010)

30. Lynd, L.R., Zyl, W.H.V., McBride, J.E., Laser, M.: Consolidated bioprocessing of cellulosic biomass: an update. Curr. Opin. Biotechnol. 16, 577-583 (2005)

31. Lynd, L.R.: Overview and evaluation of fuel ethanol from cellulosic biomass: technology, economics, the environment, and policy. Annu. Rev. Energy Env. 21, 403-465 (1996)

32. Ng, T.K., Ben-Bassat, A., Zeikus, J.G.: Ethanol production by thermophilic bacteria: fermentation of cellulosic substrates by cocultures of Clostridium thermohydrosulfuricum. Appl. Environ. Microbiol. 41(6), 1337-1343 (1981)

33. Rogers, P.: Genetics and biochemistry of Clostridium relevant to development of fermentation processes. Adv. Appl. Microbiol. 31, 1-60 (1986)

34. Turner, P., Mamo, G., Karlsson, E.N.: Potential and utilization of thermophiles and thermostable enzymes in biorefining. Microb. Cell Fact. 6, 9 (2007). doi:10.1186/1475-2859-6-9

35. Qazi, J.I.: Biotechnological potential and conservatory of extremophiles from climatically wide ranged developing countries: lesson from Pakistan. Crit. Rev. Microbiol. 39(1), 1-8 (2013). doi:10.3109/1040841X.2012.679613

36. Klinke, H.B., Thomsen, A.B., Ahring, B.K.: Inhibition of ethanol-producing yeast and bacteria by degradation products produced during pre-treatment of biomass. Appl. Microbiol. Biotechnol. 66, 10-26 (2004)

37. Nardon, L., Aten, K.: Beyond a better mousatrap: a cultural analysis of the adoption of ethanol in. Brazil. J. World Bus. 43, 261-273 (2008)

38. Singh, A., Pant, D., Korres, N.E., Nizami, A.-S., Prasad, S., Murphy, J.D.: Key issues in life cycle assessment of ethanol production from lignocellulosic biomass: challenges and perspectives. Bioresour. Technol. 101, 5003-5012 (2009)

39. Lynd, R., Currie, D., Ciazza, N., Herring, C., Orem, N.: From Consolidated bioprocessing of cellulosic biomass to ethanol using thermophilic bacteria. In: Wall, J.D., Harwood, C.S., Demain, A. (eds.) pp. 55-73. Bioenergy, Washington (2008)

40. Hild, H.M., Stuckey, D.C., Leak, D.J.: Effect of nutrient limitation on product formation during continuous fermentation of xylose with Thermoanaerobacter ethanolicus JW200. Appl. Microbiol. Biotechnol. 60, 679-686 (2003)

41. Karadag, D.: Anaerobic $\mathrm{H} 2$ production at elevated temperature $\left(60{ }^{\circ} \mathrm{C}\right)$ by enriched mixed consortia from mesophilic sources. Int. J. Hydrog. Energy 36, 438-465 (2011)

42. He, Q., Lokken, P.M., Chen, S., Zhou, J.: Characterization of the impact of acetate and lactate on ethanolic fermentation by Thermoanaerobacter ethanolicus. Bioresour. Technol. 100, 5955-5965 (2009)

43. Lovitt, R.W., Longin, R., Zeikus, J.G.: Ethanol production by thermophilic bacteria-physiological comparison of solvent effects on parent and alcohol-tolerant strains of clostridium thermohydrosulfuricum. Appl. Environ. Microbiol. 48(1), 171-177 (1984)

44. Raj, S.M., Talluri, S., Christopher, L.P.: Thermophilic hydrogen production from renewable resources: current status and future perspectives. Bioenergy Res. 5, 515-531 (2012)

45. Strickland, L.H.: The bacterial decomposition of formic acid. Biochem. J. 23(6), 1187-1198 (1929)

46. Hallenbeck, P.C., Benemann, J.R.: Biological hydrogen production; fundamentals and limiting processes. Int. J. Hydrog. Energy 27, 1185-1193 (2002)

47. Levin, D.B., Pitt, L., Love, M.: Biohydrogen production: prospects and limitations to practical application. Int. J. Hydrog. Energy 29, 173-185 (2004)

48. Hallenbeck, P.C., Ghosh, D.: Advances in fermentative biohydrogen production: the way forward? Trends Biotechnol. 27(5), 287-297 (2009)

49. Cammack, R., Frey, M., Robson, R.: Hydrogen as a fuel: learning from nature. Taylor \& Francis, London (2001)

50. Androga, D.D., Ozgur, E., Eroglu, I., Gunduz, U., Yucel, M.: Photofermentative hydrogen production in outdoor conditions. In: Minic, D. (ed.) Hydrogen energy—challenges and perspectives, pp. 77-120. In Tech, Novi Sad (2012)

51. Argun, H., Kargi, F.: Bio-hydrogen production by different operational modes of dark and photo-fermentation: an overview. Int. J. Hydrog. Energy 36(13), 7443-7459 (2011)

52. Vignais, P.M., Billoud, B., Meyer, J.: Classification and phylogeny of hydrogenases. FEMS Microbiol. Rev. 25, 455-501 (2001)

53. Kovacs, K.L., Maroti, G., Rakhelya, G.A.: Novel approach for biohydrogen production. Int. J. Hydrog. Energy 31, 1460-1468 (2006)

54. Sasikala, K., Ramana, C.V., Rao, P.R., Kovacs, K.L.: Anoxygenic photosynthetic bacteria: physiology and advances in hydrogen production technology. Adv. Appl. Microbiol. 68, 211-295 (1993) 
55. Rey, F.E., Heiniger, E.K., Harwood, C.S.: Redirection of metabolism for biological hydrogen production. Appl. Environ. Microbiol. 73, 1665-1671 (2007)

56. Rakhely, G., Kovacs, A.T., Maroti, G., Fodor, B.D., Csanadi, G., Latinovics, D., Kovacs, K.L.: A cyanobacterial type, heteropentameric NAD+ reducing $[\mathrm{NiFe}]$ hydrogenase in the purple sulphur photosynthetic bacterium, thiocapsaroseopersicina. Appl. Environ. Microbiol. 70, 722-728 (2004)

57. Kotay, S.M., Das, D.: Biohydrogen as a renewable energy resource-prospects and potentials. Int. J. Hydrogen Energy 33, 258-263 (2008)

58. Melis, A., Zhang, L., Forestier, M., Ghirardi, M.L., Seibert, M.: Sustained photobiological hydrogen gas production upon reversible inactivation of oxygen evolution in the green alga Chlamydomonas reinhardtii. J. Plant Physiol. 22, 127-136 (2000)

59. Vazquez, I.V., Varaldo, H.M.P.: Hydrogen production by fermentative consortia. Renew. Sust. Energy Rev. 13, 1000-1013 (2009)

60. vanNiel, E.W., Budde, M.A., de Haas, G.G., van der Wal, F.J., Claassen, P.A.M., Stams, A.J.: Distinctive properties of high hydrogen producing extreme thermophiles, Caldicellulosiruptor saccharolyticus and Thermotoga elfii. Int. J. Hydrogen Energy 27(11-12), 1391-1398 (2002)

61. Westermann, P., Jorgensen, B., Lange, L., Ahring, B.K.: Christensen $\mathrm{CH}$. Maximizing renewable hydrogen production from biomass in a bio/catalytic refinery. Int. J. Hydrogen Energy 32, 4135-4141 (2007)

62. Argun, H., Kargi, F., Kapdan, I.K.: Effects of the substrate and cell concentration on bio-hydrogen production from ground wheat by combined dark and photo-fermentation. Int. J. Hydrogen Energy 34, 6181-6188 (2009)

63. Ni, M., Leung, D.Y., Leung, M.K., Sumathy, K.: An overview of hydrogen production from biomass. Fuel Process. Technol. 87, 461-472 (2006)

64. Abreu, A.A., Karakashev, D., Angelidaki, I., Sousa, D.Z., Alves, M.M.: Biohydrogen production from arabinose and glucose using extreme thermophilic anaerobic mixed cultures. Biotechnol. Biofuels 5(6), 1-12 (2012). doi:10.1186/1754-6834-5-6

65. Hawkes, F.R., Dinsdale, R., Hawkes, D.L., Hussy, I.: Sustainable fermentative hydrogen production: challenges for process optimisation. Int. J. Hydrogen Energy 27(11-12), 1339-1347 (2002)

66. Levin, D.B., Chahine, R.: Challenges for renewable hydrogen production from biomass. Int. J. Hydrogen Energy 35, 4962-4969 (2010)

67. vanNiel, E.W.J., Claassen, P.A.M., Stams, A.J.M.: Substrate and product inhibition of hydrogen production by the extreme thermophile, Caldicellulosiruptor saccharolyticus. Biotechnol. Bioeng. 81(3), 255-262 (2003)

68. Zeidan, A.A., van Niel, E.W.J.: A quantitative analysis of hydrogen production efficiency of the extreme thermophile Caldicellulosiruptor owensensis OLT. Int. J. Hydrogen Energy 35, 1089-1098 (2010)

69. Verhaart, M.R.A., Bielen, A.A.M., Oost, J.V.D., Stams, A.J.M., Kengen, S.W.M.: Hydrogen production by hyperthermophilic and extremely thermophilic bacteria and archaea: mechanisms for reductant disposal. Environ. Technol. 31, 993-1003 (2010)

70. Reher, M., Gebhard, S., Schonheit, P.: Glyceraldehyde-3- phosphate ferredoxinoxidoreductase (GAPOR) and non-phosphorylating glyceraldehyde-3-phosphate dehydrogenase (GAPN), key enzymes of the respective modified Embden-Meyerhof pathways in the hyperthermophilic crenarchaeota Pyrobaculum aerophilum and Aeropyrum pernix. FEMS Microbiol. Lett. 273, 196-205 (2007)

71. Schut, G.J., Adams, M.W.W.: The iron-hydrogenase of Thermotoga maritima utilizes ferredoxin and NADH synergistically: a new perspective on anaerobic hydrogen production. J. Bacteriol. 191, 4451-4457 (2009)
72. Hallenbeck, P.C.: Fermentative hydrogen production: principles, progress and prognosis. Int. J. Hydrogen Energy 34, 7379-7389 (2009)

73. Sahlstrom, L.: A review of survival of pathogenic bacteria in organic waste used in biogas plants. Bioresour. Technol. 87(2), 161-166 (2003)

74. vanGroenestijn, J.W., Hazewinkel, J.H., Nienoord, M., Bussmann, P.J.: Energy aspects of biological hydrogen production in high rate bioreactors operated in the thermophilic temperature range. Int. J. Hydrogen Energy 27, 1141-1147 (2002)

75. Conrad, R., Wetter, B.: Influence of temperature on energetics of hydrogen metabolisminhomoacetogenic, methanogenic, and other anaerobic-bacteria. Arch. Microbiol. 155(1), 94-98 (1990)

76. Hussy, I., Hawkes, F.R., Dinsdale, R., Hawkes, D.L.: Continuous fermentative hydrogen production from a wheat starch coproduct by mixed microflora. Biotechnol. Bioeng. 84(6), 619-626 (2003)

77. Hartmann, H., Ahring, B.K.: A novel process configuration for anaerobic digestion of source-sorted household waste using hyper-thermophilic post-treatment. Biotechnol. Bioeng. 90(7), 830-837 (2005)

78. Kleerebezem, R., van Loosdrecht, M.: Mixed culture biotechnology for bioenergy production. Curr. Opin. Chem. Bio. 18(3), 207-212 (2007)

79. Temudo, M., Kleerebezem, R., van Loosdrecht, M.: Influence of the $\mathrm{pH}$ on (open) mixed culture fermentation of glucose: a chemostat study. Biotechnol. Bioeng. 98(1), 69 (2007)

80. Sreethawong, T., Niyamapa, T., Neramitsuk, H., Rangsunvigit, P., Leethochawalit, M., Chavadej, S.: Hydrogen production from glucose-containing wastewater using an anaerobic sequencing batch reactor: effects of COD loading rate, nitrogen content and organic acid composition. Chem. Eng. J. 160, 322-332 (2010)

81. Basak, N., Das, D.: Photofermentative hydrogen production using purple non-sulfur bacteria Rhodobactersphaeroides O.U. 001 in an annular photobioreactor: a case study. Int. J. Hydrogen Energy 33, 911-919 (2009)

82. Akkerman, I., Janssen, M., Rocha, J., Wijffels, R.H.: Photobiological hydrogen production: photochemical efficiency and bioreactor design. Int. J. Hydrogen Energy 27, 1195-1208 (2002)

83. Koku, H., Eroğlu, I., Gündüz, U., Yücel, M.: Aspects of the metabolism of hydrogen production by Rhodobactersphaeroides. Int. J. Hydrogen Energy 27, 1315-1329 (2002)

84. Chen, Y., Wang, P., Liu, C., Cheng, H.-M.: Improved hydrogen storage performance of $\mathrm{Li}-\mathrm{Mg}-\mathrm{N}-\mathrm{H}$ materials by optimizing composition and adding single-walled carbon nanotubes. Int. J. Hydrogen Energy 32, 1262-1268 (2007)

85. Argun, H., Kargi, F., Kapdan, I.K.: Light fermentation of dark fermentation effluent for bio-hydrogen production by different Rhodobacter species at different initial volatile fatty acid (VFA) concentrations. Int. J. Hydrogen Energy 33, 7405-7412 (2008)

86. Chen, S.-D., Lee, K.-S., Lo, Y., Chen, W.-M., Wu, J.-F., Lin, C.Y., Chang, J.-S.: Batch and continuous biohydrogen production from starch hydrolysate by Clostridium species. Int. J. Hydrogen Energy 33, 1803-1812 (2008)

87. Zaman, K., Khan, M.M., Ahmad, M.: Factors affecting commercial energy consumption in Pakistan: progress in energy. Renew. Sust. Energ. Rev. 19, 107-135 (2013)

88. Asif, M., Muneer, T., Maubleu, S.: Prospects of solar water heating for textile industry in Pakistan. Renew. Sust. Energ. Rev. 10, 1-23 (2006)

89. Khalid, A., Mahmood, M., Asif, M.: Muneer T:solar assisted, precooled hybrid desiccant cooling system for Pakistan. Renew. Energy 34, 151-157 (2009)

90. Privatisation Commission (of Pakistan), Privatization through Public Private Partnership (ppp): Policy Guidelines and Program http://www.privatisation.gov.pk/about/Privatisation\%20through\% 
20PPP\%20\%28Latest\%29.htm (2007). Accessed 30 October 2013

91. Naureen, A.: Cost Benefit and Risk Analysis of Biofuel Production in Pakistan, Master's thesis. Swedish university of agricultural sciences. Uppsala. http://stud.epsilon.slu.se (2013)

92. Dawn News, Pakistan. http://x.dawn.com/2012/09/03/millsfor-new-policy-on-bagasse-fuelled-power-cogeneration (2012). Accessed 12 August 2013

93. Harijan, K., Memon, M., Uqaili, M.A., Mirza, U.K.: Potential contribution of ethanol to the transport sector of Pakistan. Renew. Sust. Energ. Rev. 13(1), 291-295 (2009)

94. Ali, T., Huang, J., Yang, J.: An overview of biofuels sector of Pakistan: status and policies. Int. J. Econ. Res. 03(1), 69-76 (2012)

95. Chaudhary, N., Qazi, J.I.: Ethanologenic potential of thermophilic bacterium and yeast from acid saccharified sugarcane bagasse. Pak. J. Zool. 40(2), 99-103 (2008)
96. Ahlam AA-WS: Microbiological converson of waste fruits and vegitables into ethanol. The University of the Punjab, Department of Zoology (2005)

97. Ibraheem, O., Ndimba, B.K.: Molecular adaptation mechanisms employed by ethanologenic bacteria in response to lignocellulose-derived inhibitory compounds. Int. J. Biol. Sci. 9(6), 598-612 (2013)

98. Volfová, O., Suchardová, O., Panoš, J., Krumphanzl, V.: Ethanol formation from cellulose by thermophilic bacteria. Appl. Microbiol. Biotechnol. 22(4), 246-248 (1985)

99. Extreme heat wave in Pakistan. http://www.pakmet.com.pk/ (2010). Accessed 10 February 2014 